\title{
Outreach to Migrant Farmworkers Through a Pesticide Safety Initiative
}

\author{
Diana Flannery ${ }^{1}$, Mary Portis ${ }^{1}$, and Joey Adame ${ }^{2}$ \\ ${ }^{1}$ California State University, Chico \\ ${ }^{2}$ Butte County Office of Education
}

\begin{abstract}
Resumen
In order for migrant farmworkers to engage in pesticide safety actions they need to understand the health risks related to pesticide exposure and the steps they can take to reduce and mitigate exposure. Most importantly, beyond education, migrant farmworkers need the products and resources necessary to take pesticide safety action. This article explains how we created a service learning project to provide migrant farmworkers in our area with the supplies they need for a successful pesticide safety program.

Para que sea posible que los trabajadores migrantes de campo tomen precauciones con pesticidas, ellos tienen que entender los riesgos de salud relacionados con la exposición a pesticidas y los pasos que deberían tomar para reducir y mitigar su exposición. Aún más importante que la educación, los trabajadores migrantes de campo necesitan los productos y recursos necesarios para tomar precauciones con pesticidas. Este artículo explica como nosotros creamos un proyecto de aprendizaje, para proveerle a los trabajadores migrantes de campo en nuestra área con las provisiones necesarias para llevar a cabo un exitoso programa de precauciones a la exposición a pesticidas.
\end{abstract} (C) 2003 Californian Journal of Health Promotion. All rights reserved.

Keywords: Migrant Farmworkers, Pesticide Safety, Service Learning, California State University, Chico

\section{Introduction}

A year ago we were packing unsold T-shirts from a fund raiser into storage boxes when a student asked what we were planning to do with the shirts. We replied that since the T-shirts were now out of date we were just sending them to the warehouse. She asked if she could have a couple for her father who worked in the fields. He didn't always have a clean shirt to put on after work. We had over sixty shirts. Did she know of others who could use a shirt? She assured us that there were a lot of farmworkers who would benefit from new shirts.

The next day in an environmental health class the topic was pesticides and in an instant the human connection between pesticides and the health toll they take was crystal clear. The curriculum changed that day to include an indepth study on pesticides and farmworkers with an emphasis on creating a service learning project that could make a difference in the 


\section{About Migrant Education - Our Community Partner}

As faculty members on a college campus, we did not have a direct link to the farmworkers in our area, but our campus houses a Mini-Corp Program and that seemed like a possible partnership. The Mini-Corp Program provides tutoring to migratory elementary students to give them the academic and social support they need to succeed in their course work and help them stay in school. The tutors come from a migrant family background and are full-time college students who are pursuing teaching credentials. Mini-Corps tutors work with migratory students during the school year and summer school as role models to strengthen the relationships among students, teachers, family members, and members of the community.

The Mini-Corp Program is part of California's Migrant Education Program (MEP) which is supported by federal and state laws. The state law is a response to federal requirements for educating migratory students. Migrant Education supports two kinds of programs designed to strengthen the school, community, and family experiences of children and their families. Migrant Education is responsible for planning, implementing, and evaluating programs and projects that support the education of migrant students and their families. Some programs are developed locally by migrant education regional offices in collaboration with the school districts that enroll migratory students. Other programs are administered statewide and are designed to meet specific needs of students such as those related to health, family literacy, and summer school. Migrant Education provides various health education programs at farmworker camps in their region.

Ms. Lupe Guillen, the CSUC campus MiniCorps Coordinator, scheduled a meeting with the Butte County Office of Migrant Education Region II Health and Family Specialist Joey Adame. We discussed items that were needed by the area migrant farmworkers and ways to distribute the items. We expressed an interest in developing a community partnership and addressed the principles of a community partnership (see Appendix A). We followed this meeting with in-depth interviews with the college students enlisted as Mini-Corp teachers. The consensus from these students and community leaders who are working directly with farmworker families was that farmworkers need the following items to help protect themselves from the hazards of pesticide-related poisonings: soap, detergent, changes of clothing, hats, warm clothes, long sleeve shirts, floor mats, slippers or house shoes, water jugs and coolers, bedding, towels, sunscreen, and lip protectant.

\section{Part I}

The partnership and program developed and expanded over 2 semesters. The first semester students in the environmental health course began community fundraising and initiated a campus clothing drive. Recognizing a language barrier existed; students and faculty worked directly with bilingual Migrant Education health aides and conducted a pesticide safety education program for them. Students also attended two farmworker communities as support staff as we teamed up with Migrant Education during their outreach programs. In one camp, hundreds of items were given away by the CSUC students and in the second community event, a children's holiday workshop was featured. During the holiday workshop, students displayed the new items they solicited as gifts and helped the migrant children gift wrap these pesticide safety items for family members (see Figures $1 \& 2$ ). The CSUC students played games with the children and provided snacks while the parents attended a health education seminar. Several bilingual college students and migrant health aides helped facilitate the interactions.

\section{Part II}

As faculty and community partners developed a relationship, expanding the program was discussed. Continued fundraising, targeting more farmworker communities, and involving CSUC students in the health education programming were planned for the following semester. This paper addresses pesticide safety guidelines, the objectives and components of a pesticide safety initiative, student reflections on service learning, and a summary of the outreach projects. 


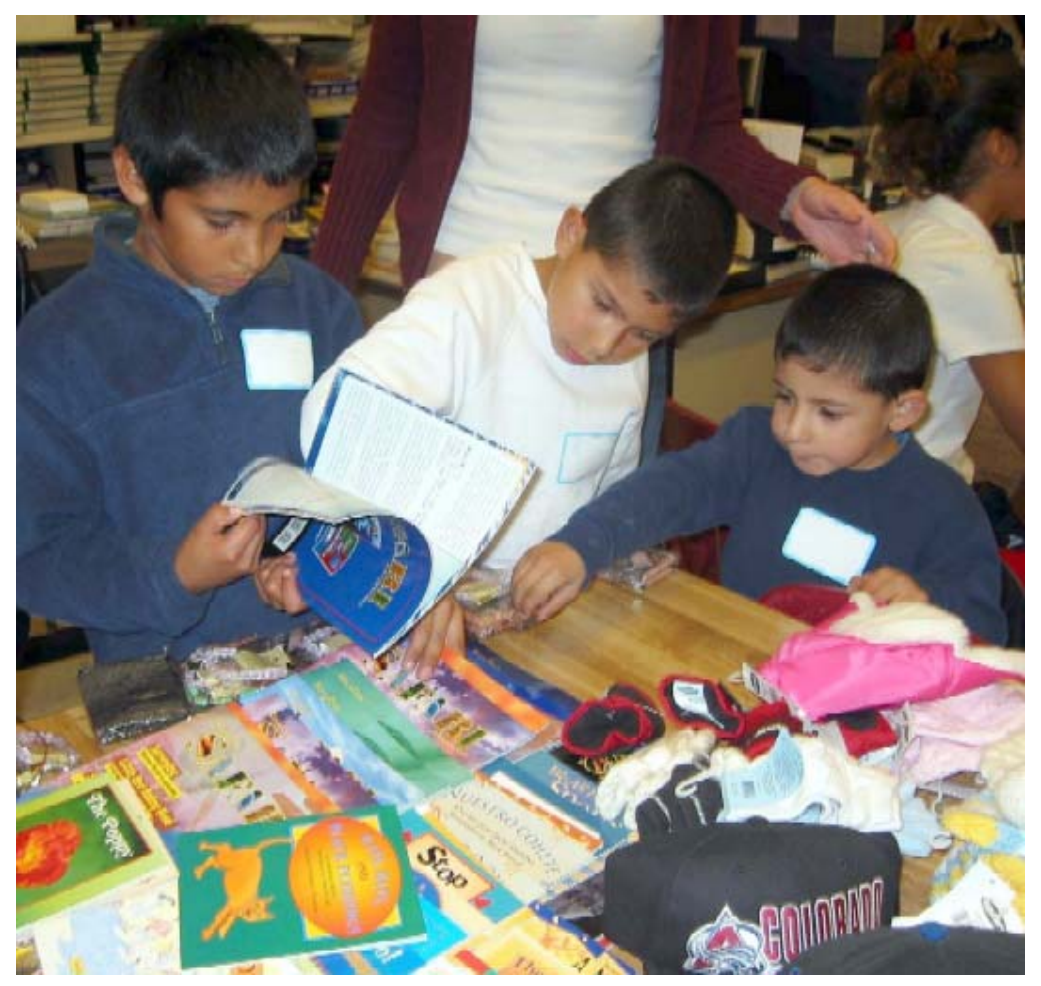

Figure 1

Boys Choosing New Books

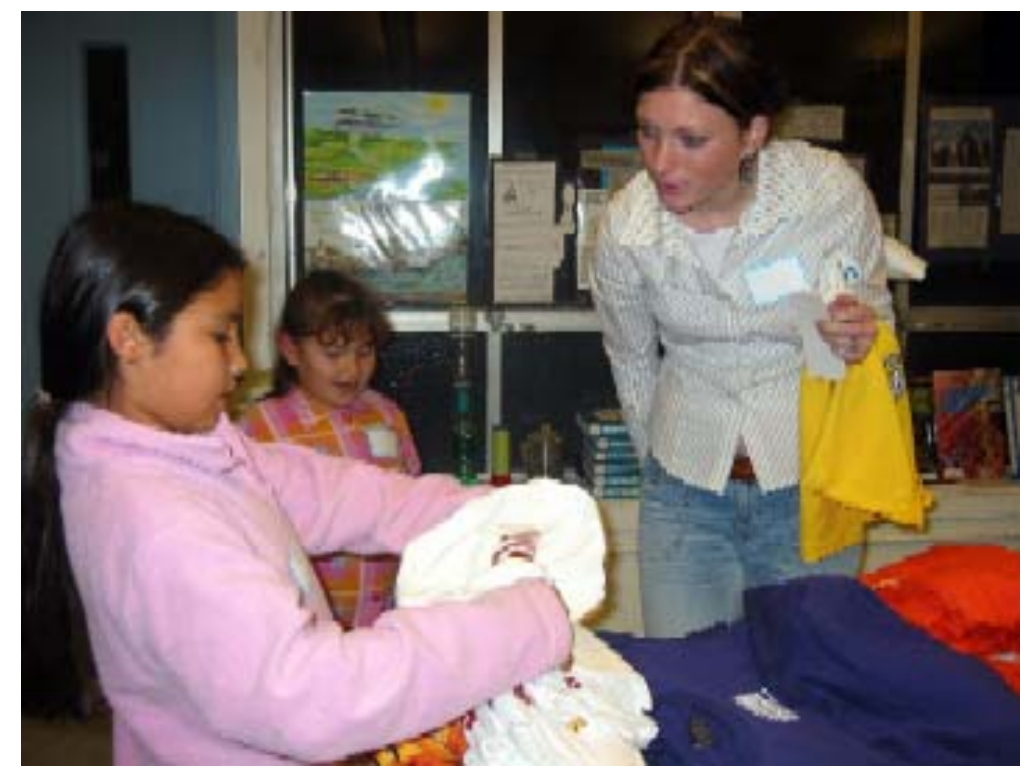

Figure 2

CSUC Student and Girl Choosing Gift Items 


\section{Farmworkers in California}

California is rich in growing fields but many of us do not see its poorer side. This other California is the home of our farmworkers. "Hundreds of thousands of children, teens, and adults labor each year in fields, orchards, and packing sheds across the United States. They pick lettuce and cantaloupe, weed cotton fields, and bag produce. They climb rickety ladders into orchards, stoop low over chili plants, and "pitch" heavy watermelons for hours on end. Many begin their work days either in the fields or en route to the fields-in the middle of the night. Twelve-hour workdays are common" (Human Rights Watch Staff, 2000). Farmworker families need assistance on many levels. Enforcement of workers' rights, pesticide safety, assurance of adequate housing, increased availability of traditional and nontraditional education, and free and accessible health care these are the minimum conditions necessary to ensure that all agricultural laborers, have a safe and healthy life.

Agricultural work is the most hazardous and grueling employment for children and adults in the United States. It is also the least protected and the poorest paid. Farmworkers are regularly exposed to pesticides - while mixing or applying pesticides; during planting, weeding, thinning, irrigating, pruning, and harvesting crops; living in or near treated fields; or eating pesticide-contaminated food. As a result, farmworkers face greater risk of exposure to hazardous pesticides than any other sector of society. There were over 4,000 cases of farmworker pesticide poisoning reported in California from 1991-1996 (Reeves, Katten, \& Guzman, 2002). Farmworkers continue to face unacceptable risks of exposure to dangerous pesticides (see PowerPoint Presentation 1, The Health Threats of Pesticides to Farmworkers, and PowerPoint Presentation 2, Información Sobre Los Pesticidas).

\section{How to Reduce Pesticide Exposure}

Only eliminating hazardous pesticides and replacing them with safer, less toxic ones is a sustainable solution to protecting farmworkers and the environment. However, farmworkers need help reducing their risk until sustainable agriculture is a reality.

There are several simple actions farmworkers can take to reduce their exposure and thus protect their health. Farmworkers should know that pesticides may be on or in plants, soil, irrigation water, or drifting from nearby applications.

Basic actions to prevent pesticide poisonings are:

$\checkmark$ Following directions and/or signs about keeping out of treated or restricted areas.

$\checkmark$ Washing before eating, drinking, using chewing gum or tobacco, or using the toilet.

$\checkmark$ Wearing work clothing that protects the body from pesticide residues

$\checkmark$ Washing/showering with soap and water, shampoo hair and put on clean clothes and shoes after work.

$\checkmark$ Washing work clothes separately from other clothes before wearing them again.

$\checkmark$ Using a door mat or removing shoes before entering the home.

$\checkmark$ Washing immediately in the nearest clean water if pesticides are spilled or sprayed on the body and, as soon as possible, showering, shampooing, and changing into clean clothes .

People serving migrant farmworkers should know (Reeves, Murphy, \& Morales, 2003):

When exposed to agricultural pesticides, workers need to work together to develop a plan of action including identifying witnesses.

$\checkmark$ All agricultural workers must receive adequate pesticide training on a regular basis.

$\checkmark$ State authorities must regularly issue maximal allowable fines for violations of worker safety laws - especially those regarding worker training, access to services, and poisoning investigations.

$\checkmark$ Medical services must be made available. 
As global citizens, pesticide overuse effects everyone. Organizations such as the Pesticide Action Network (Reeves et al., 2002) seek broader goals for reducing pesticide risks among farmworkers. They challenge the Department of Pesticide Regulation and county agricultural commissioners to:

$\checkmark$ Eliminate use of the most hazardous pesticides to reduce the problem of acute as well as chronic pesticide poisoning.

$\checkmark$ Promote safe and sustainable alternatives.

$\checkmark$ Reduce pesticide drift through improved regulations including buffer zones and a phase out of aerial spraying.

$\checkmark$ Reduce exposure to pesticide residue by enforcing proper warning signs in the fields.

$\checkmark$ Strengthen enforcement of existing laws by issuing significant fines.

$\checkmark$ Improve farmworker access to pesticide information and healthcare.

$\checkmark$ Improve pesticide incident investigation.

$\checkmark$ Improve pesticide illness reporting.

$\checkmark$ Reduce pesticide exposure among children through better childcare and housing.

\section{Challenges in Addressing Pesticide Safety}

Simple products such as detergent and clean clothes would not by themselves alleviate the pesticide problem. Discussion with the migrant education aides revealed a significant number of barriers to the simple pesticide safety actions listed above. Lack of awareness of the dangers of pesticides is a big barrier. Further complicating their risk is that farmworkers are exposed not to a single pesticide but to multiple pesticides of various classifications and to a variety of doses over extended periods of time. Some pesticide exposures do not create any immediate attention-getting symptoms. They are part of the work day that may not seem as important as more pressing survival issues.

Understanding chronic effects of pesticide poisoning are limited because the effects are rarely recognized or documented. However, evidence is mounting that certain pesticides are linked to cancer, birth defects, immunotoxicity, neurotoxicity, behavioral impairment, endocrine disruption, reproductive dysfunction, respiratory diseases such as asthma, skin conditions, and developmental disabilities (Faultline Magazine, 2002; Solomon, Ogunseitan, \& Kirsch, 2000).

Poverty is a common thread throughout the barriers. Like the father of our student many farmworkers simply do not have enough clothes to change into a clean set after work each day. A shower or even water and soap are not available for use at the field work sites. Even if a shower were available, farmworkers may not want to clean up and then continue their hot and dusty trek home by walking, biking or riding in open trucks only to arrive home hot and sweaty (Human Rights Watch Staff, 2000).

The lack of water for washing follows some farmworkers to their homes. There is a wide range of housing conditions among migrant farmworkers. While water at home is not an issue to all farmworkers, others are living in cars, under bridges, and in crowded contrived shelters in the fields and other undeveloped areas. Water is not always available for hand washing in the fields. Sometimes the only water is ice-cold, and many Mexicans prefer not to put cold water on hot hands.

Like clothing, soap and laundry detergent cost money. Washing work clothes separate from children's clothes can cost additional, unnecessary money. Moreover, laundromats can also be difficult to get to on a regular basis.

Farmworkers in the US are primarily Mexican, speak little English, and often do not read Spanish. Many farmworkers believe that if they can't see a pesticide, taste or smell it, it isn't there. It is important to get across the idea of pesticide residues. In one program, pesticide residues were called the 'invisible terror' (Clay, 2000). The authors cautioned that even though workers may not see or taste some pesticides, they still may be there. Their program focused on ways to reduce farmworker risk, and stressed hand washing, wearing protective clothing, and cleaning work clothes separate from their regular clothes. Another challenge they found was encouraging the workers to shower as soon as they returned home from work. They found that some workers prefer to wait until their bodies 'cool down.' A third barrier identified 
was the inability to tell their boss what they needed because the farm owners didn't speak Spanish.

Perhaps the biggest barrier facing farmworker safety is fear of job reprisal if they report any pesticide poisoning or need time off to see a doctor. Very few farmworkers have health insurance and do not realize they have legal protections by workers compensation laws for workplace injuries in California (Reeves et al., 2003). Many workers are unfamiliar with symptoms of pesticide exposure which often mimic flu-like symptoms. It is important for farmworkers to identify witnesses in the case of acute poisonings to help document the event. Farmworkers can be misdiagnosed, often can't afford to see a doctor, and also lack transportation to medical services

\section{The Objectives of Our Pesticide Safety Project}

With the needs and barriers of the farmworkers in mind we formed the following objectives:

1. Create culturally appropriate, low literacy, action-oriented messages for migrant education health aides and the farmworkers on how to avoid or mitigate their risk of pesticide exposure.

2. Solicit soap, towels, bedding, door mats, duffle bags, water jugs, change of clothing, sunscreen, hats, and laundry detergent from manufacturers and stores for distribution at the migrant farm camps (see Figure 3).

3. Collect gently used garments from the larger community.

4. Host Farmworker Appreciation Days at the migrant camps to distribute the pesticide safety products and present the pesticide safety messages.

\section{Fundraising}

Solicitation takes time. Our first job was to create a generic solicitation letter (see Appendix B). Our second job was to determine to whom to send the letter. We were so surprised and energized by the generous donations from local businesses as well as national companies (see Acknowledgements). We received items from approximately 25 percent of the businesses solicited. We were lucky to find storage in an campus office warehouse. After receiving items, a thank you letter with our non-profit tax identification code was sent to each donor (see Appendix C).

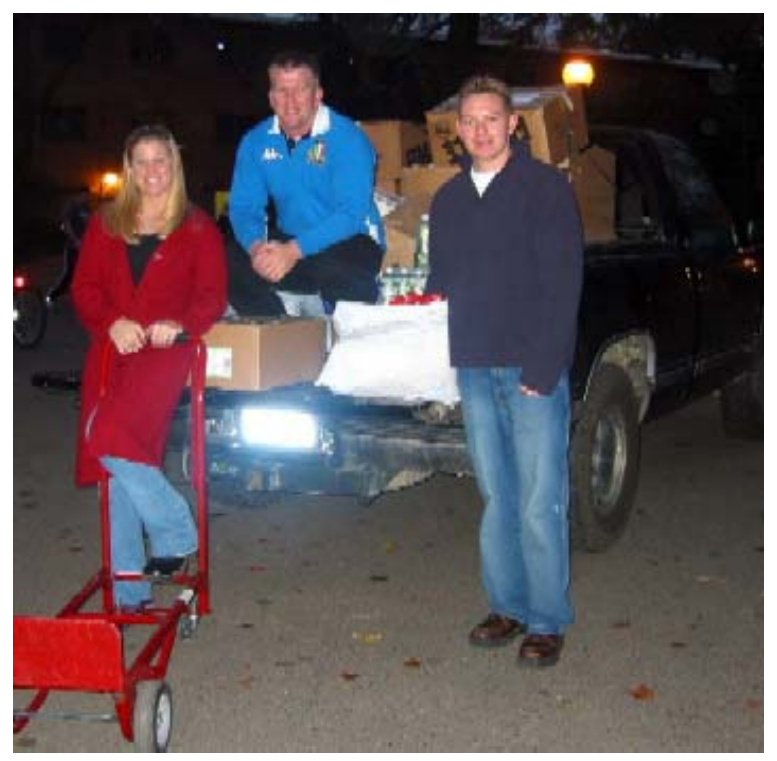

Figure 3

Truck loaded with donations and student volunteers 


\section{Collection of Gently Used Garments}

Students collected gently used items of their own and their friends and family. Thousands of clothing items were collected in a one month period (see Figure 4).

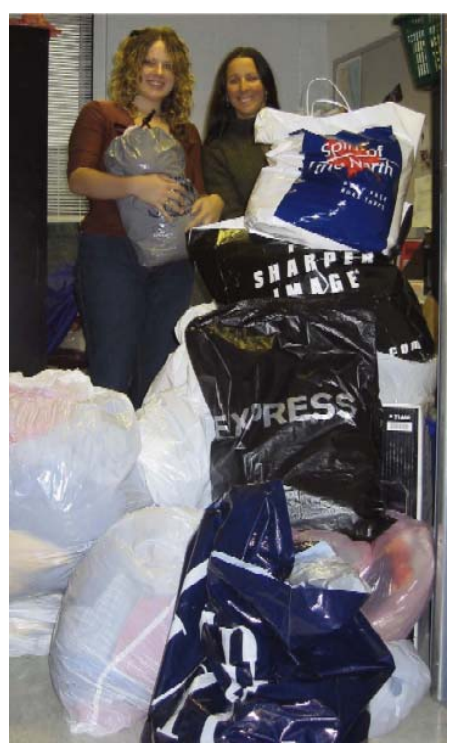

Figure 4

First Round of Gently Used Donations

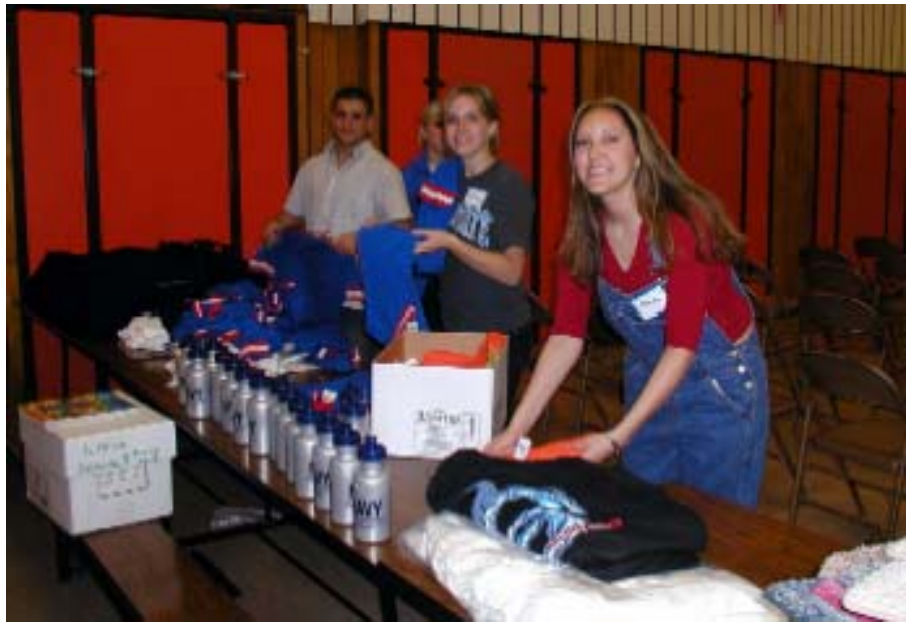

Figure 5

Preparing Safety Kits
Implementation of the Farmworker Appreciation Days

Every pesticide safety program followed the format below:

1. Welcome and Introductions.

2. Raffling of various safety prizes such as water bottles.

3. Biomagnification demonstration to show how pesticide exposure builds in humans especially those who are working directly with the crops (see Appendix D, PowerPoint 3).

4. Biomagnification Blues Song (see Appendix E, Audio 1).

\section{Creating the Pesticide Safety Kits}

Prior to each migrant camp program, students packed individual pesticide safety kits for each program participant (see Figure 5, Video Clip 1). The kits contained: T-shirt, towel, hat, soap, shampoo, deodorant, lotion, sunscreen, toothpaste, toothbrush, lip protectant, and water bottle. 


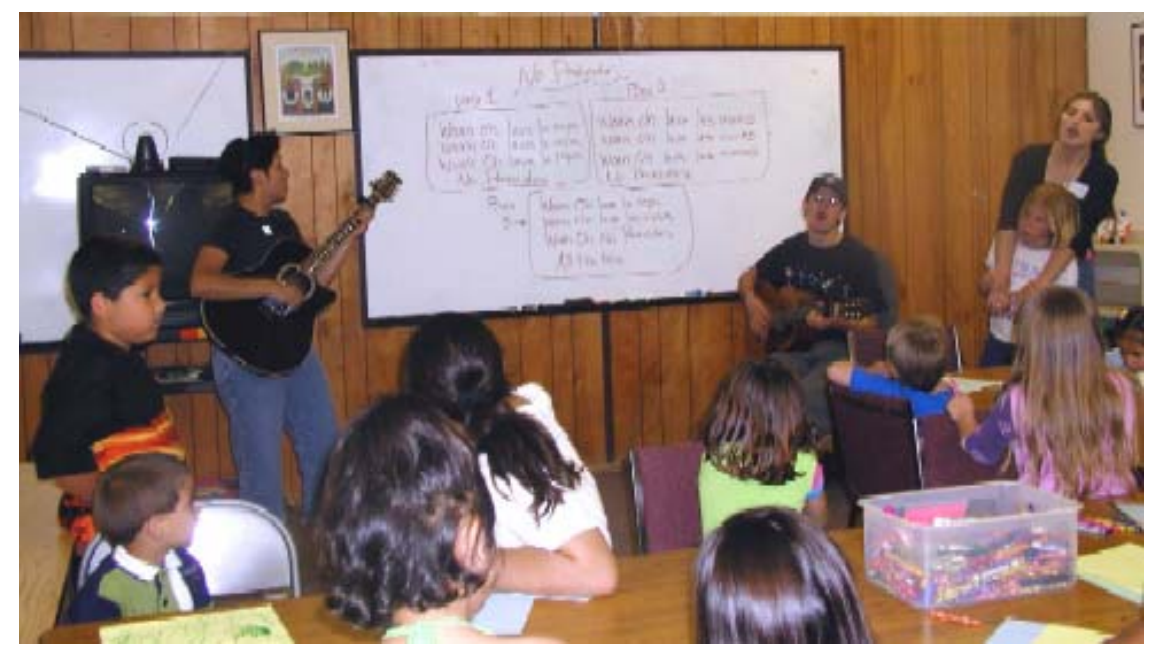

Figure 6

Children Practicing No Pesticidas

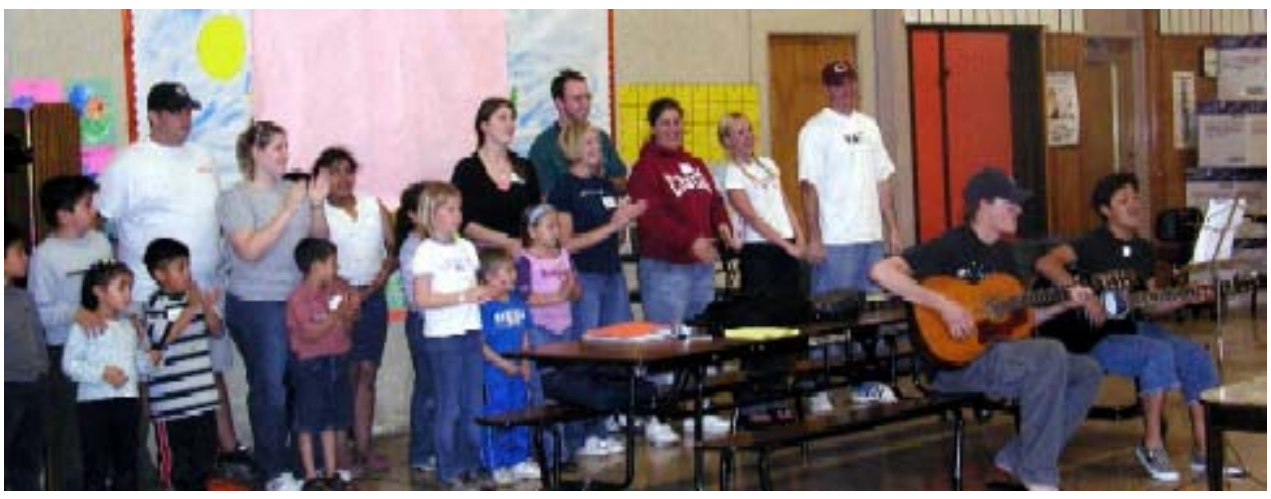

Figure 7

Students and Children Singing No Pesticidas

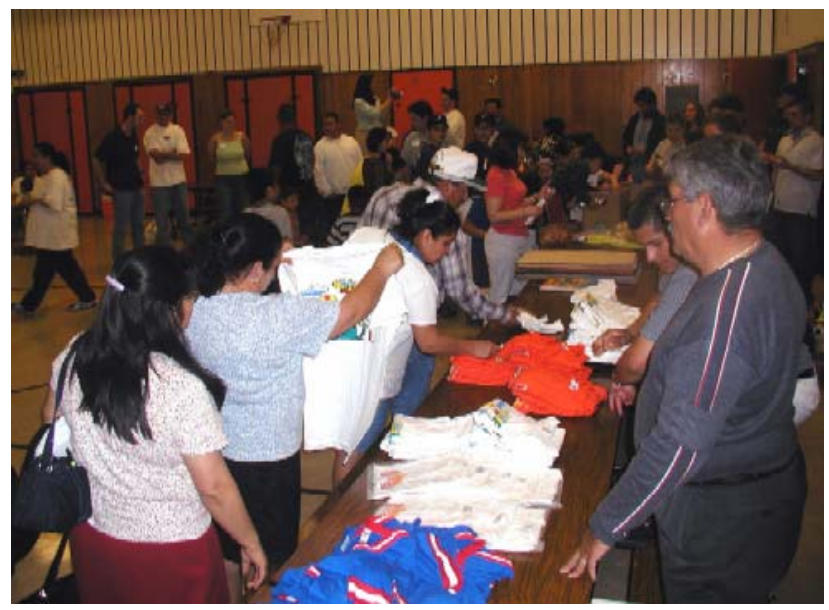

Figure 8

Community Participants Receiving Safety Kits and T-Shirts 


\section{Responses of the University Students}

Reflection is an important part of service learning. As part of the course, students were asked the following questions to help them describe their experiences:

- How did their participation in the pesticide safety project helped make them a better advocate and citizen?

- How has the community service project helped them learn more about environmental health in their local community?

- How have the class readings, discussions, and service projects enhanced their environmental awareness or activism?

- What did they learn about their selves as a result of this course and service project?

- Identify ways to make this community service experience more effective for others.

Through reflective writings and class discussions, we felt students learned a great deal from this service project. They personally benefited from this community based activity and felt good about themselves. Stacey stated: "what we did for the migrant farmworkers and their families was such a wonderful thing. They are not fortunate to have all of the clothing and food that they need, so I am glad that we could provide them with some of the things that they needed. I really felt good giving my used clothes to the migrant workers and their families. I am also proud of all the things that our class solicited. Everyone seemed to take it seriously."

Students were able to be spokespersons on migrant farmworker conditions and had to justify and articulate their needs to solicitors. As Sarah writes: "for the clothing drive, I felt it was especially great to see the community people and businesses who wanted to help. My role in this clothing drive was to not only collect clothes for these migrant farmworkers, but educate people on the conditions in which they live and work. Many people just are not informed of their situation and the fact that yes, even in California, we have laborers who are underpaid and overlooked."

Another student was able to make the link theory and practice. Anna stated: "students were interested in studying the health threats to migrant farmworkers and this service project helped make real connections between classroom learning and community outreach."

Studying the health problems of people in our community can be a consciousness raising experience as one student wrote: "The discussions and readings about pesticides and migrant farmworkers blew me away. Not only are working conditions poor and the pay is poor, but their health is being jeopardized as well."

Knowing the health needs are many among migrant families and meeting them directly can generate a variety of emotions among the students. John, a future teacher wrote, "I felt extremely guilty that I couldn't do more, but at the same time I felt so good when I was able to give what I could. This was my favorite event mainly because I got to see the lives we touched first hand."

Service learning empowers students to see their own contributions to the community and is a way for students to give back to their community. Alex shared: "This is the first time that the material I was learning in class was being supplemented with real world interactions. After performing the volunteer activities, I feel like I have become a better citizen because now I care about the community that I live in and know that I can do things to help."

The fundraising and pesticide safety program help students apply environmental activism in their life. As Elizabeth demonstrated: "I was able to talk about the cause and educate people like my family back home and my roommates on the issue while I urged them to add to my donation pile. I was impressed with the quality of most of the items that were donated from my friends and family. I felt a strong sense of 
community collaboration when I saw the piles and piles of clothes in Dr. Flannery's office. It was pretty awesome."

Students also commented on the service experience and how it prepared them for the profession of health education. Service learning calls upon students, in partnership with the community, to apply their knowledge to community settings. Mary agrees: "Half trying, you can walk away from any class and say 'I learned something', in this class I'm walking way with 'I learned something, I helped others, and I feel less helpless about big picture of issues that affect me and the environment.' All in all, I'm a better person for it."

Service learning in a migrant farmworker community aids in the development of cultural competence for our students. Helping students apply classroom learning to community settings is often a foundation for future service. Several students have volunteered to stay involved even after the course ended. Meredith reflects: "The night in Gridley was so cool. I can't believe how much stuff we collected and how many people ended up going to the event. All of the migrant farmers were so grateful for all of the stuff. The kids were my favorite part because they were so excited to get to give their families stuff that they got to pick out of their own. I hope in the future to continue helping people in this sort of manner. It is so fulfilling."

\section{Summary}

During the fall semester, students enrolled in Environmental Health collected new t-shirts, holiday ornaments, lip protectant, over the counter medicines, water jugs, jewelry, books, food, shoes, socks, hats, carpet samples, and school supplies from local, regional, and nationwide companies. Moreover, a campus wide program, Second Chance Week collected thousands of gently used items that were distributed to migrant families and the Health Professional Association, a student service organization was also involved by collecting canned goods for the migrant farm community.

During the fall semester 2002, donations were distributed to migrant children in over 15 different schools throughout Butte County by college students enrolled in the mini-corps migrant education program. The authors of this paper and select Environmental Health students also participated in a pesticide safety program to help educate migrant health aides on this important topic. Migrant Education health aides then helped distribute many items to the families along with a pesticide safety message.

Two migrant camps were specifically targeted by the fall semester Environmental Health students. A holiday workshop was hosted by the CSU, Chico students in Gridley, CA, where the gifts were selected by the migrant children and then gift wrapped for family members. The children played games and wrapped gifts while the parents attended a health education seminar. Hundreds of new and used items were taken to the Williams farmworker camp to help ensure a change of clothing after work in the fields.

The second semester we expanded our pesticide safety message by developing specific curriculum that included a biomagnification exercise, a safety lecture, live music, a safety skit, distribution of safety kits, and children's games. The students broadened their fundraising efforts nationwide and the business community response was worth the effort. We also conducted a campus wide collection for tote bags and collected hundreds of cloth bags for our safety kits. Two migrant farmworkers communities, Hamilton City and Oroville, were reached in the spring of 2003. We were able to distribute thousands of dollars worth of needed supplies to migrant farmworker families. We also raised awareness on the risks of pesticides in the migrant farmworker community and the community at large.

There were many challenges in developing a community partnerships and integrating service learning in a college curriculum. Logistics, scheduling, student attendance and attitudes, student skill development, community acceptance and participation, partnership expectations, balance of power, development of mutual trust, and overstretched resources and personnel are continuous challenges in this type of program. Meeting these challenges takes 
time, effort, patience and a willingness to consider a diversity of viewpoints.

We feel as a result of our partnership with Migrant Education there were community, faculty, and student rewards. A lively, interactive, and family based program was developed for the farmworkers and their families. Hundreds of families gained access to more resources by receiving pesticide safety supplies and skills on how to reduce their pesticide risk. Community members felt cared about by the nearby university students and enjoyed a new learning experience. Students enrolled in an environmental health course developed competency in community outreach, fundraising, and cultural competence. Students gained resume and portfolio items, boosted selfconfidence, and had fun. Student reflective writing responses were overwhelming positive. For faculty, this experience provided a sense of community and purpose and an opportunity for research. This work helped us stay current with our professional skills. Our students engaged in scholarly work that addressed one of the most pressing problems of society, were devoted to the advancement of the local community or region, and engaged in experiential learning anchored in real-life problems. A community partnership where one group had access to the community and the other could enhance program development and initiate fundraising was worth the effort.

\section{References}

Clay, R. (2000). Let's work together: Connecting research and the community. Environmental Health Perspectives, 108, A500. Retrieved April 15, 2003, from http://ehpnet1.niehs.nih.gov/docs/2000/108-11/niehsnews.html

Connors, K., \& Seifer, S. D. (Eds.)(2000). Partnership perspectives (Issue 2, Vol 1). San Francisco: Community-Campus Partnerships for Health.

Cornell, J. (1979). Sharing nature with children. Nevada City, CA: Dawn Publications.

Faultline Magazine Staff. (August 8, 2002). Latino farmworkers face greater risk of cancer. Retrieved April 15, 2003, from http://www.faultline.org/news/2002/08/UFWcancer.html

Human Rights Watch Staff. (2000). Fingers to the bone: United States failure to protect child farmworkers. Retrieved April 15, 2003, from http://www.hrw.org/reports/2000/frmwrkr/index.htm\#

Parks, C. P., \& Straker, H. O. (1996). Community assets mapping: Community health assessment with a different twist. Journal of Health Education, 27, 321-323.

Reeves, M., Katten, A., \& Guzman, M. (2002). Fields of poison 2002. California farmworkers and pesticides (pp. 4-7). Retrieved April 15, 2003 from http://www.panna.org/campaigns/docsWorkers/CPRreportexsum.pdf

Reeves, M., Murphy, T., \& Morales, T. C. (2003). Farmworker women and pesticides in California's central valley (pp. 1-14). Retrieved April 15, 2003, from http://www.panna.org/resources/documents/CVEnglish2-20.pdf

Solomon, G., Ogunseitan, O. A., Kirsch, J. (2000). Pesticides and human health. A resource for health care professionals. Physicians for Social Responsibility and Californians for Pesticide Reform (pp. 1-60). Retrieved on April 15, 2003, from http://www.psrla.org/pahk.pdf

\section{Acknowledgements}

The list of donors and items solicited in 2002-2003 are listed below.

\begin{tabular}{|l|l|}
\hline \multicolumn{1}{|c|}{ Thank you! } & \multicolumn{1}{|c|}{$\begin{array}{c}\text { We want to thank all of you who supported the } \\
\text { Farmworker Safety Project! }\end{array}$} \\
\hline $\begin{array}{l}\text { Action Impact } \\
\text { Ducks Unlimited } \\
\text { Fifth Sun } \\
\text { Fleet Feet }\end{array}$ & $\begin{array}{l}\text { Items included t-shirts, sports clothing, sports } \\
\text { equipment, and hats. }\end{array}$ \\
\hline
\end{tabular}




\begin{tabular}{|c|c|}
\hline Thank you! & $\begin{array}{l}\text { We want to thank all of you who supported the } \\
\text { Farmworker Safety Project! }\end{array}$ \\
\hline $\begin{array}{l}\text { Gottschalks } \\
\text { Joyce Panencaldo } \\
\text { Old Navy } \\
\text { Pacific Sun } \\
\text { Royal Team Sports } \\
\text { Sacramento Kings } \\
\text { Safeway } \\
\text { Sierus } \\
\text { SMS Screenprint } \\
\text { Sports Fever } \\
\text { SWAT/FAME } \\
\text { Sun Dog } \\
\text { Visa-Bob Ray }\end{array}$ & \\
\hline $\begin{array}{l}\text { Blistex } \\
\text { Dr. Lauri Barbro--Beckett - Dentist } \\
\text { Dr. Stephen Vannucci--Dermatologist } \\
\text { Unilever } \\
\text { Wyeth Consumer Health Care }\end{array}$ & $\begin{array}{l}\text { Items included lip protectant (ChapStick }{ }^{\circledR} \text { and } \\
\text { Blistex } \AA) \text {, sunscreen, toothbrushes, tooth paste, } \\
\text { dental floss, Centrum Vitamins } \AA \text {, Dristan } \AA \text {, and } \\
\text { Anacin } \AA \text {. }\end{array}$ \\
\hline $\begin{array}{l}\text { Jeanne Thomas, PhD, Dean of } \\
\quad \text { Behavioral and Social Sciences, } \\
\quad \text { CSUC } \\
\text { Arnethia Okelo } \\
\text { AS Bookstore, CSUC } \\
\text { AS Recycle - Barbara Kopicki, Christie } \\
\quad \text { Stotts } \\
\text { Butte College } \\
\text { Campus Alcohol and Drug Education } \\
\quad \text { Center (CADEC) } \\
\text { CSUC Health Professionals Club } \\
\text { CSUC Warehouse } \\
\text { Dr. Mary Portis } \\
\text { Four Winds of Indian Education } \\
\text { Panhellenic Council, CSUC } \\
\end{array}$ & $\begin{array}{l}\text { Items included books, clothing, t-shirts, soap, } \\
\text { cookies, shaving cream, canned goods, used clothing, } \\
\text { and tote bags. } \\
\text { Special thanks to the students in Environmental } \\
\text { Health } 02 / 03 \text { for the used clothing, fundraising } \\
\text { efforts, and their creative work. }\end{array}$ \\
\hline $\begin{array}{l}\text { Alice and Adrian Roberts } \\
\text { Arbys } \\
\text { Bird-In-Hand } \\
\text { Coalition for Urban/Rural Environmental } \\
\quad \text { Stewardship } \\
\text { Coca-Cola Bottling Company of CA } \\
\text { Dan Kempers } \\
\text { Frito Lay } \\
\text { Heather Mello } \\
\text { M \& E Enterprises } \\
\text { Mary Schreider } \\
\text { Office Depot } \\
\text { Rick Bair } \\
\text { Streamlight } \\
\text { Team World }\end{array}$ & $\begin{array}{l}\text { Items included coupons, safety brochures, water } \\
\text { bottles, backpacks, water coolers, flashlights, } \\
\text { jewelry, wallets, socks, toys, books, food, and cash } \\
\text { donations. } \\
\text { Special thanks to the following students for their } \\
\text { additional assistance in this project: } \\
\text { Bev Bursack } \\
\text { Shea Conkey } \\
\text { Mike McClure } \\
\text { Heather Mello } \\
\text { Nicole Nepstead } \\
\text { Liz Rhodes } \\
\text { Lee Shawver }\end{array}$ \\
\hline
\end{tabular}




\begin{tabular}{|l|l|}
\hline \multicolumn{1}{|c|}{ Thank you! } & \multicolumn{1}{|c|}{$\begin{array}{c}\text { We want to thank all of you who supported the } \\
\text { Farmworker Safety Project! }\end{array}$} \\
\hline $\begin{array}{l}\text { United States Navy } \\
\text { W. F. Lanam } \\
\text { World End Imports }\end{array}$ & $\begin{array}{l}\text { Christie Stotts } \\
\text { Chonie Vargas }\end{array}$ \\
\hline $\begin{array}{l}\text { Jaime Adame } \\
\text { Ivonne Knoefler } \\
\text { Samuel Llamas } \\
\text { Ronnie Rosales } \\
\text { Alberto Vargas } \\
\text { Rosa Vargas }\end{array}$ & $\begin{array}{l}\text { Butte County Office of Education, Migrant Education } \\
\text { Program, Promotores de Salud / Health Educators }\end{array}$ \\
\hline
\end{tabular}

Author Information

Diana Flannery, $\mathrm{PhD}$

Department of Heath and Community Services

California State University, Chico

Chico, CA 95929-0505

E-Mail: dflannery@,csuchico.edu

Ph. 530-898-4993

Mary Portis, DrPH

Department of Heath and Community Services

California State University, Chico

Chico, CA 95929-0505

E-Mail: mportis@csuchico.edu

Ph. 530-898-4994

Joey Adame, MFCC

Migrant Education - Region II Area IV

Butte County Office of Education

Chico, CA 95926

E-Mail: jadame@,bcoe.org

Ph. 530-879-7500 


\section{Appendix A \\ Principles of Community Partnership and Formalizing the Partnership}

\section{Principles of Community Partnership}

1. Partners have agreed upon mission, values, goals and measurable outcomes for the partnership.

2. The relationship between partners is characterized by mutual trust, respect, genuineness, and commitment.

3. The partnership builds upon identified strengths and assets, but also addresses areas that need improvement.

4. The partnership balances the power among partners and enables resources among partners to be shared.

5. There is clear, open and accessible communication between partners, making it an on-going priority to listen to each need, develop a common language, and validate/clarify the meaning of terms.

6. Roles, norms, and processes for the partnership are established with the input and agreement of all partners.

7. There is feedback to, among and from all stakeholders in the partnership with the goal of continuously improving the partnership and its outcomes.

8. Partners share the credit for the partnership's accomplishments.

9. Partnerships take time to develop and evolve over time.

\section{Formalizing the Partnership with a Partnership Agreement}

1. Involve all key partners.

2. Agree on the partnership's purpose, goals, and objectives.

3. Determine each partner's expectations and anticipated benefits of the partnership.

4. Determine the roles, responsibilities, and key tasks of each partner, along with an accompanying timeline.

5. Anticipate the partnership's outcomes and benefits.

6. Anticipate the partnership's financial and staffing considerations.

7. Anticipate the partnership's products and resulting copyright and ownership issues.

8. Plan an evaluation process.

9. Determine a publicity plan.

From: Connors, K., \& Seifer, S. D. (Eds.) (2000). Partnership Perspectives. Issue II, Volume 1. San Francisco, CA: Community-Campus Partnerships for Health. 


\section{Appendix B \\ Sample Solicitation Letter}

February 6, 2003

Dear

California is rich in growing fields but many of us do not see its poorer side. This other California is the home of our farmworkers. Agricultural work is the most hazardous and grueling employment for children and adults in the United States. It is also the least protected and the poorest paid. "Hundreds of thousands of children, teens, and adults labor each year in fields, orchards, and packing sheds across the United States. They pick lettuce and cantaloupe, weed cotton fields, and bag produce. They climb rickety ladders into orchards, stoop low over chili plants, and "pitch" heavy watermelons for hours on end. Many begin their work days-either in the fields or en route to the fields-in the middle of the night. Twelve-hour workdays are common" http://www.hrw.org/reports/2000/frmwrkr/index.htm\#. Farmworker families need assistance on all fronts. Enforcement of workers' rights, pesticide safety, assurance of adequate housing, increased availability of traditional and nontraditional education, and free and accessible health care - these are the minimum conditions necessary to ensure that all agricultural laborers, have a safe and healthy life.

I am a faculty member teaching the course, Environmental Health, at Chico State. In class we are studying the health status of migrant farmworkers and their families. As part of the course, we are involved in a service learning project to outreach to a number of migrant farmworker camps in the surrounding counties to provide needed pesticide safety information and protective clothing and supplies. We also want to show them our appreciation for the work that they do by providing them with a change of clothing, cleaning supplies, and products that we have collected from local individuals and businesses. We see this as a way for all of us to lighten the burden of many migrant families and to thank them for their hard labor in providing food to our tables.

I am asking you to donate goods or gift certificates or checks (payable to the Health

Professionals Club) by March 1 and we will take your offerings to the families March through May. Items of need include new clothing and shoes for men, women, teens, and children, hats, coolers, water jugs, tote and gear bags, laundry soap, bathing essentials, sunscreen/lotion, and anything else you think they might need. Merchandise that cannot be sold are welcome! Please call me if you have any questions (530.898.4993).

Thank you for your support,

Diana Flannery, PhD

Associate Professor 


\section{Appendix C \\ Thank You Letter}

March 10, 2003

Dear

Many thanks for your generous donation of for the migrant farmworker pesticide safety project. The federal tax ID Number of the Health Professionals Club is . The generous value/amount of your gift was

This spring, students enrolled in Environmental Health are soliciting items for the pesticide safety campaign and will distribute kits to help protect farmworker from pesticide exposures. Soap, towels, bedding, door mats, duffle bags, water jugs, change of clothing, sunscreen, hats, etc. will be part of the kits and pesticide safety messages will be shared to help the farmworkers and their families reduce their risk.

Please feel free to contact me (530.343.1985) if you have any questions or if you would like to donate any other items to our community project. Once again, thank you for your generous contributions and for helping to lighten the burden of many migrant families. Your donation will be acknowledged in the Volume 1, Issue 2 of the California Journal of Health Promotion (http://www.cjhp.org/).

Sincerely,

Diana Flannery, PhD

Department of Health and Community Services

California State University, Chico

Chico, CA 95929-0505 


\section{Appendix D \\ Biomagnification Demonstration}

As we go higher up the food chain, more and more poisons concentrate in the tissues of animals. This process is called biomagnification. Birds like eagles and other animals have been harmed by poisons in the environment. This exercise helps demonstrate where humans fit into the food chain. This demonstration has been adapted from Joseph Cornell's Sharing Nature with Children. The second activity has been developed to help farmworkers understand the added pesticide risks that they experience.

\section{Biomagnification Exercise}

1. As participants come into the room hand them a card (with one side written in Spanish, the other side in English) of the following (see PowerPoint Presentation 3):

Yellow Cards - alfalfa, wheat, corn, soybeans, grasses

Purple Cards - goats \& pigs, cows \& chickens, fish

Blue Card - human

2. Participants holding the yellow cards are asked to come to the front of the room and kneel on the ground. Tell the group: I've noticed that the plants are having trouble with some insects, so I'm going to spray with a pesticide. The cards are read and pesticides used on these crops are discussed. I name a "bad actor" pesticide that has been linked to that specific crop. These bandanas that I'm placing your heads - one per plant - signify poison that has accumulated in the plant (see Figure 9). [The color card scheme used in the photos below were different from the one identified in the PowerPoint Presentation above.]

3. Then the people holding the purple cards are asked to come up and stand behind the yellow card holders. Now I'd like the herbivores (plant eaters) to reach down and eat the plants. You do this by taking the plant's bandana and putting it on the top of your head. Keep eating until all the plants are eaten. An additional bandana is placed on the herbivores head to illustrate pesticides ingested from the air and water.

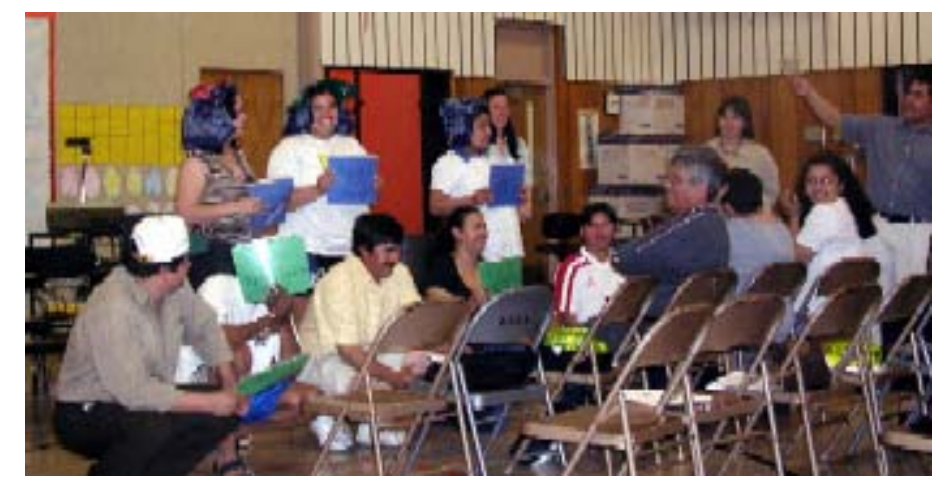

Figure 9

Community Members Participating in Biomagnification Exercise

4. Then the person holding the blue card stands behind the last group. A bandana is placed on the human's head to illustrate pesticides ingested from the air and water. Let's have the predators eat 
the herbivores. Poisons like herbicides and pesticides are dangerous to animals and humans because when they are digested the poison can stay in the tissues of living things. Who has the highest concentration of poison in them? The human highest on the food chain now has all the bandanas on his/her head. The terms biomagnification and bioaccumulation are discussed. Each participant is given a gift for volunteering.

\section{Farmworker Pesticide Exposure Demonstration}

1. Farmworkers are exposed to poisons through the food chain as well as through the air they breathe, the water they drink, and the work they do. But men, women, and children working near and around agriculture are exposed to poisons and pesticides more than any other group. This next exercise illustrates the added risks and sources of exposure of pesticides for farmworkers.

2. Give another set of participants cards with the following information in English and Spanish:

a. Yellow Cards - play close to the ground; weaker immune system; eat, drink, breathe more per body size; put things in their mouth; embryo/fetus at risk; work and play near agricultural fields

b. Purple Cards - mixing or applying pesticides; during planting, weeding, pruning and irrigating; during harvesting and packing; living in or on treated fields; eating contaminated food

c. Grey Cards - exposed to drift; exposed to field residues

d. Blue Card - migrant farmworker

2. Participants holding the yellow cards are asked to come to the front of the room and kneel on the floor. Pesticide use is increasing in California and children are vulnerable to poisons in their homes, yards, schools, parks, and communities. These yellow cards illustrate the reasons why poisons are more dangerous to children and how they can be exposed. These bandanas I'm placing on your head help show us routes of pesticide exposure and how early the process of biomagnification begins in life. As you read each card, place a bandana on the head of each volunteer.

3. Then the people holding the purple cards are asked to come up and stand behind the yellow card holders. Many children in the farmworker community also become farmworkers. Now have the row of "farmworkers" take the bandanas from the row of "children" in front of them and place the bandanas on their own heads. Farmworkers and their families face a greater threat of suffering from pesticide-related illnesses. These threats include acute poisonings and long term effects such as cancer and birth defects. Farmworkers have many different jobs and work around many different crops. There can be many sources of exposure to many different types of pesticides. How many of you have done this type of work? Read the purple cards and place a bandana on each person's head illustrating a potential source of pesticide exposure.

4. Then ask the volunteers holding the grey cards to stand behind the purple card holders. These grey cards illustrate how most acute related pesticide poisonings occur. Add a bandana while you say, being exposed to drift accounts for 44 percent of all poisonings and field residues account for 33 percent of all poisonings. Ask the grey card holders to place the bandanas from the row in front of them on their heads to indicate a lifetime occupational risk of pesticide exposures. How many of you know someone who has experienced a pesticide related poisoning? There are groups working to phase out aerial spraying and "bad actor" pesticides in California. 
5. Now ask the person holding the blue card to stand behind the group. Have the person representing the "migrant farmworker" take the bandanas from the row in front of him/her to demonstrate of lifetime risk of exposure. Farmworkers have many sources of exposure to pesticides through the work they do, air they breathe, water they drink, and even early exposures as children. Further complicating their risk is that farmworkers are exposed not to a single pesticide, but to multiple pesticides of various types, to a variety of doses over extended periods of time. Migrant farmworkers in California have a life expectancy of only 49 years, and have higher rates of various cancers and occupational injuries. This program today is to encourage you to take pesticide exposure seriously, find ways to reduce your risk and help you protect your family. What ways do you protect yourself and your family already? Are they other ways farmworkers and their families can be exposed to pesticides?

6. Thank all the participants and answer any questions. Each volunteer receives a shirt or water bottle for participating.

Next, the song Biomagnification Blues is sung or played (Appendix E, Audio 1).

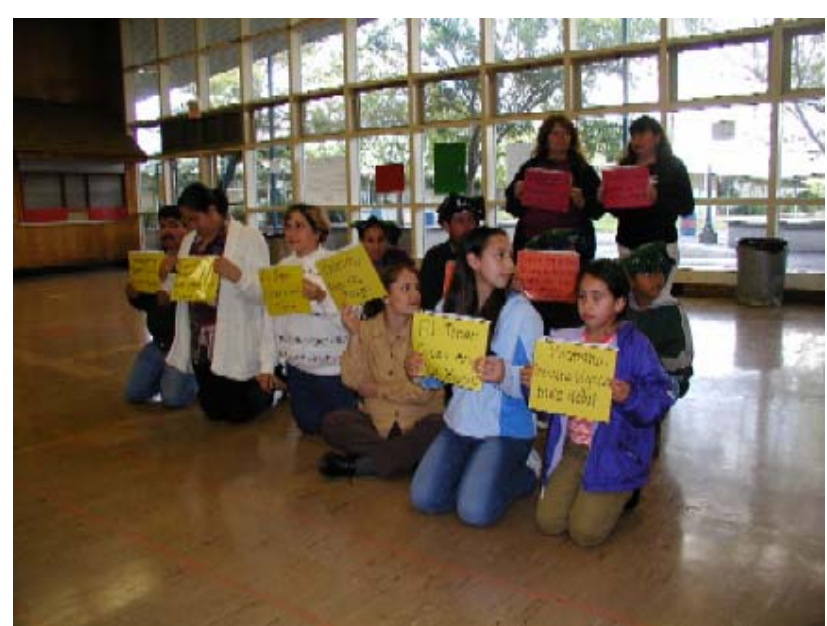

Figure 10

Biomagnification Pesticide Exposure Exercise

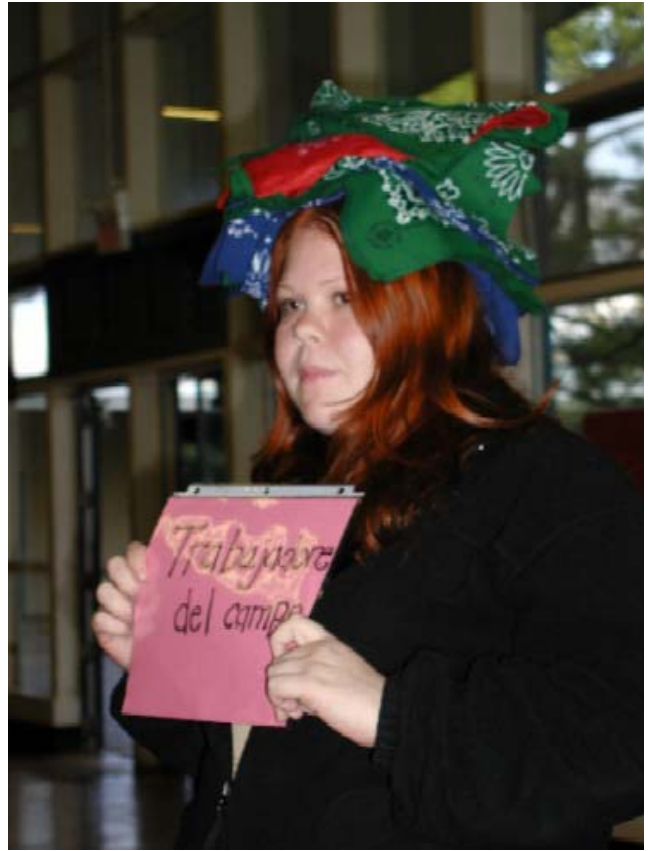

Figure 11

Girl Representing Farmworker Pesticide Exposure 


\section{Appendix E \\ Biomagnification Blues Lyrics}

\section{Biomagnification Blues by Chonie Vargas}

\section{To hear the song, click $\underline{\text { Audio } 1}$}

Farmworkers everywhere uh huh beware

You see these pesticides... No they don't play fair

They travel by drift and field residue

Yes they're bound to get you and your friends too

I've got the Biomagnification Blues

Yes, I do

Now it starts during planting when you weed and prune

And pack all the harvest and pretty soon

They are all over you and your children too

Yes, they're all over you and I don't know what to do

I've got the Biomagnification Blues

Yes, I do

Oh oh I can't sleep No no I can't eat

Now don't drink the water and take off your shoes and

Wipe your feet - Cause they come in the house

Yes they come in the house where you sleep

Pesticides like to creep

I've got the Biomagnification Blues

Yes, I do

So go tell your Madre and your Hermano too

And Cousin Jorge cause they are movin' up the food chain

Hitchin a ride yes they're hitchin a ride

In your food and it makes me so blue

I've got the Biomagnification Blues

Yes, I do

Farmworkers everywhere uh huh beware

You see these pesticides no they don't play fair

They travel by drift and field residue

And then a cancer begins to grow inside of you

That's why I've got the Biomagnification Blues

Oh yes I do I've got the blues

Oh yes I do I've got the Biomagnification Blues

Oh yes I do 


\section{Appendix F \\ Farmworker Skit \\ Written by Nicole Nepstead and Environmental Health Students}

(See Video Clip 2)

Anna (Farmworker)

Miguel Sanchez (health educator)

Doctor Juarez (Emergency Room Doctor)

Amalia (Farmworker)

Boss

Jaime: (Farmworker)

\section{(Two workers in a field)}

Anna: We're working around strawberries this week. I heard they use a lot of pesticides like Methyl Bromide on them. We better make sure we keep ourselves protected.

Amalia: Pesticides? I'm not worried about pesticides.

Anna: Are you kidding? Did you know that pesticides can cause rashes, headaches, blurred vision, chest pain, excessive sweating, nausea and vomiting? Methyl Bromide specifically can cause headaches, nausea and vomiting, and flu like symptoms. I even heard that one person went into a coma and died. There are also some long term effects that are caused by pesticides like cancer, birth defects, and other reproductive and development problems.

Amalia: Well, that's not a problem because I'm working in an organic field.

Anna: Wrong!! Pesticide drift accounts for $40 \%$ of contamination.

Amalia: I never knew pesticides could be so harmful! I should go talk to my cousin Jaime. He was over exposed to Methyl Bromide in the field this morning, when they were spraying. He was complaining of flu-like symptoms and went home.

Anna: Let's go find Jaime and take him to the boss.

\section{(Jaime is sitting in a chair)}

Amailia: Hey Jaime, Let's go talk to the boss, I think we should take you to the doctor since you were over exposed to Methyl Bromide this morning when you were working in the field.

Jaime: No, I'm fine, I'll just take a break.

Amalia: No, I really think we should go talk to the boss. I'll go with you.

\section{(Boss enters scene)}

Amalia: Hey boss, I think Jaime may have been over exposed to the pesticides you sprayed on the strawberry fields this morning.

Boss: Were you out in the field this morning? 
Jaime: Yes, I was.

Boss: Well, we need to get you to the emergency room. Methyl Bromide can have some really bad effects on you. First let's get you changed into a clean shirt and have you wash your hands to prevent further contamination.

\section{(Doc enters scene)}

Doc Juarez: Hello, how can I help you?

Boss: I believe Jaime may have been over exposed to Methyl Bromide in the field this morning.

Doc Juarez: Well, it is a good thing that you came in Jaime. If you hadn't there is a possibility that the pesticide can cause injury to the brain and nerves, lungs, and throat. If you are exposed to a high dose of it, it can even cause damage to the liver and kidneys. What we are going to do is keep you here at the hospital over night so that we can monitor you.

Jaime: Am I going to be OK?

Doc Juarez: (to Jaime) Not to worry, delayed effects and long term effects are not likely to occur. Some information to know if you are exposed to pesticides again are:

- Immediately rinse the exposed skin with clean water

- Go to the doctor-ask your boss to drive you. Don't drive if you're feeling sick.

- Wash with soap and water as fast as possible and put on clean clothes

- Wash contaminated clothes separately from other clothing.

- And if possible always ask your boss for the name of the pesticides. You have legal right to ask for this information.

Doc Juarez: (to boss). Did you talk to your employees about pesticide safety?

Boss: No, I haven't.

Doc Juarez: You are supposed to educate your employees on pesticide safety. Let me refer you to my health educator Miguel and he will hand out some farmworker appreciation kits that will have some useful items and a few goodies in them.

Boss and Jaime: Thank you doctor Juarez.

The Next Day.

(Go to see Miguel the health educator)

Miguel: Hello. Here is your farm work appreciation kit with safety supplies like a fresh change of clothing, soap, towels, a door mat for your home, a hat, sunscreen, lip protectant, a fruit bar, water bottle, and hat. Please keep this tote bag with you and remember to use precautions against pesticide poisoning. 


\section{Appendix G \\ Pesticide Safety Song \\ No Pesticidas by Chonie Vargas \& Lee Shawver \\ Sung to the tune of Listen to the Music by the Doobie Brothers \\ To hear song, click Audio 2 or Video Clip 5 to see performance of this song}

Necesitamos protegernos de los peligros

De estos productos quimicos

En el ambiente

Yes, they're everywhere

Cuandro trabaja con frutas y verdura

Hay un riesgo muy serio

Las pesticidas volan por todo

Estan en el aire, en la ropa y en los pulmones

\section{Chorus:}

Woah oh.....Lava la ropa

Woah oh.... Lava la ropa

Woah oh.... Lava la ropa

No pesticidas

You see pesticidas they fly through the air

And live in the fields - workers mix and

Apply them using the same hands to eat a meal

Without washing

Pesticides travel to the mouth

In to our stomachs

Where they can't find a way out

Herbicides and fumigants are deadly irritants

Children and their size are most at risk

They play so close

To the ground

Where they put in their mouth

All the neat things they found

\section{Chorus:}

Woah oh.....Lava las manos

Woah oh.....Lava las manos

Woah oh.....Lava las manos

No pesticidas

\section{Repeat 2nd Verse}

\section{Chorus:}

Woah oh.....Lava la ropa

Woah oh......Lava la manos

Woah oh...... No pesticidas

All the Time 